This Health Hazard Evaluation (HHE) report and any recommendations made herein are for the specific facility evaluated and may not be universally applicable. Any recommendations made are not to be considered as final statements of NIOSH policy or of any agency or individual involved. Additional HHE reports are available at http://www.cdc.gov/niosh/hhe/reports

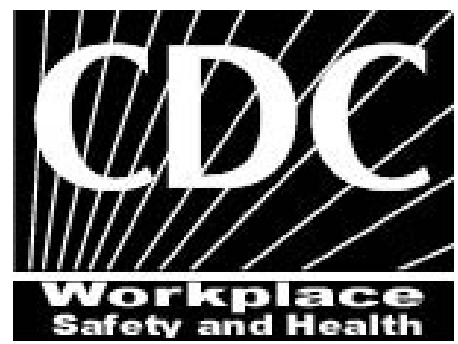

NIOSH HEALTH HAZARD EVALUATION REPORT:

HETA \#2003-0114-2924

Felker Brothers Corporation

Marshfield, Wisconsin

\title{
January 2004
}

DEPARTMENT OF HEALTH AND HUMAN SERVICES

Centers for Disease Control and Prevention

National Institute for Occupational Safety and Health

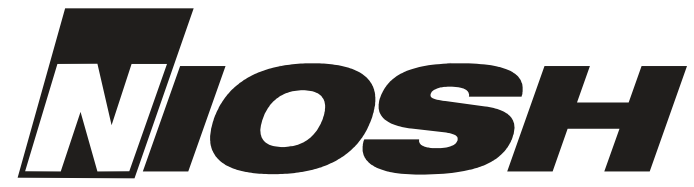




\title{
PREFACE
}

The Hazard Evaluations and Technical Assistance Branch (HETAB) of the National Institute for Occupational Safety and Health (NIOSH) conducts field investigations of possible health hazards in the workplace. These investigations are conducted under the authority of Section 20(a)(6) of the Occupational Safety and Health (OSHA) Act of 1970, 29 U.S.C. 669(a)(6) which authorizes the Secretary of Health and Human Services, following a written request from any employer or authorized representative of employees, to determine whether any substance normally found in the place of employment has potentially toxic effects in such concentrations as used or found.

HETAB also provides, upon request, technical and consultative assistance to Federal, State, and local agencies; labor; industry; and other groups or individuals to control occupational health hazards and to prevent related trauma and disease. Mention of company names or products does not constitute endorsement by NIOSH.

\section{ACKNOWLEDGMENTS AND AVAILABILITY OF REPORT}

This report was prepared by Ronald Hall, Daniel Rhodes, and Elena Page of HETAB, Division of Surveillance, Hazard Evaluations and Field Studies (DSHEFS). Field assistance was provided by Chad Dowell, Chandran Achutan, and Donald Booher. Analytical support was provided by Data Chem Laboratories. Desktop publishing was performed by Robin Smith. Review and preparation for printing were performed by Penny Arthur.

Copies of this report have been sent to employee and management representatives at Felker Brothers Corporation and the OSHA Regional Office. This report is not copyrighted and may be freely reproduced. Single copies of this report will be available for a period of three years from the date of this report. To expedite your request, include a self-addressed mailing label along with your written request to:

\author{
NIOSH Publications Office \\ 4676 Columbia Parkway \\ Cincinnati, Ohio 45226 \\ 800-356-4674
}

After this time, copies may be purchased from the National Technical Information Service (NTIS) at 5825 Port Royal Road, Springfield, Virginia 22161. Information regarding the NTIS stock number may be obtained from the NIOSH Publications Office at the Cincinnati address.

For the purpose of informing affected employees, copies of this report shall be posted by the employer in a prominent place accessible to the employees for a period of 30 calendar days. 


\section{Highlights of the NIOSH Health Hazard Evaluation}

\section{Evaluation of metal exposures at Felker Brothers Corporation}

On December 23, 2002, the National Institute for Occupational Safety and Health (NIOSH) received a union request from the International Brotherhood of Boilermakers regarding worker exposures to chromium and nickel compounds during the manufacturing of stainless steel products and fabricated piping systems at Felker Brothers Corporation in Marshfield, Wisconsin.

\section{What NIOSH Did}

- We collected air samples on workers during cutting, welding, grinding, and pickling operations.

- We talked to employees about health concerns in the workplace.

- We looked at Illness and Injury reports for the past 5 years.

\section{What NIOSH Found}

- Some workers may be exposed to nickel and hexavalent chromium above NIOSH criteria.

- Some workers may be exposed to manganese above American Conference of Governmental Industrial Hygienist ${ }^{\circledR}$ criteria.

- Sampling results indicate highest concentrations for nickel, manganese, and hexavalent chromium occur when workers weld inside large stainless steel pipes or when welding fins on large pipes.

- Area air samples for ozone indicate concentrations above NIOSH criteria and the potential to exceed other occupational criteria if continuous welding is done inside the pipes throughout the work shift.

- At the time of our evaluation, the types of cancers linked to nickel and chromium compound exposures have not been reported among current or former workers.

- Welding fumes, acid vapors, ozone, general plant dust, and general plant ventilation could contribute to irritant symptoms reported by some workers.

\section{What Felker Brothers Managers Can Do}

- Put controls (i.e., local exhaust ventilation) in areas where sample results indicate exposures above criteria.

- Re-evaluate worker exposures after controls have been put in place.

- Do not allow eating, drinking, or smoking in work areas.

- Support communication between worker representatives and management on the plant's safety/ergonomics team.

- Improve housekeeping practices by avoiding dry-sweeping and use wet clean-up methods (i.e., mopping) or HEPA filter vacuums. [Don't use wet methods in areas where it could cause potential electrical or safety hazards.]

- Protect workers from potential fall hazards.

\section{What the Felker Brothers Employees Can Do}

- Use controls as instructed.

- Do not eat, drink, or smoke in work areas.

- Report health and safety concerns to management and safety/ergonomics team.

- Follow plant safety and health guidelines.

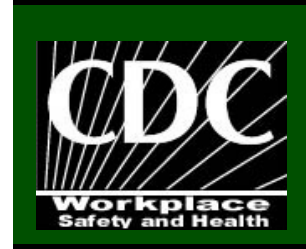

What To Do For More Information:

We encourage you to read the full report. If you would like a copy, either ask your health and safety representative to make you a copy or call $1-513 / 841-4252$ and ask for HETA Report \#2003-0114-2924 


\title{
Health Hazard Evaluation Report 2003-0114-2924 \\ Felker Brothers Corporation \\ Marshfield, Wisconsin \\ January, 2004
}

\author{
Ronald M. Hall, MS, CIH \\ Daniel Rhodes, MD, MPH \\ Elena Page, MD, MPH
}

\section{SUMMARY}

On December 23, 2002, the National Institute for Occupational Safety and Health (NIOSH) received a request from the International Brotherhood of Boilermakers regarding worker exposures to chromium and nickel compounds during the manufacture of high-quality, corrosive-resistant stainless steel products and fabricated piping systems at the two Felker Brothers Corporation facilities in Marshfield, Wisconsin. Union officials also expressed concerns about potential carcinogenic effects of these exposures.

On February 5, 2003, NIOSH investigators made an initial site visit to gather information on stainless steel cutting, welding, grinding, and pickling processes. An in-depth industrial hygiene evaluation was conducted during May 28-29, 2003. In addition, a NIOSH physician conducted private medical interviews with 23 employees.

Personal breathing zone (PBZ) air sampling was conducted on employees during stainless steel cutting, welding, grinding, and pickling operations. PBZ air samples were collected for elements (various metal compounds including nickel and chromium), total welding fumes, hexavalent chromium $\left(\mathrm{Cr}^{\mathrm{VI}}\right)$, ozone, nitrogen dioxide, carbon monoxide, and inorganic acids. Carbon dioxide, temperature, and relative humidity were also measured.

PBZ air samples indicated the potential for some workers to be exposed to nickel and $\mathrm{Cr}^{\mathrm{VI}}$ concentrations above the NIOSH recommended exposure limit (REL) and to manganese above the American Conference of Governmental Industrial Hygienists' (ACGIH $\left.{ }^{\circ}\right)$ Threshold Limit Value (TLV®). The highest concentrations for nickel, manganese, and $\mathrm{Cr}^{\mathrm{VI}}$ occurred during operations in which workers welded inside large stainless steel pipes or welded fins on a large stainless steel pipe. Two detector tube results for ozone also indicated concentrations exceeding the NIOSH REL ceiling limit and the potential to exceed ACGIH, and the Occupational Safety and Health Administration (OSHA) occupational criteria (if continuous welding occurs throughout the work shift) during welding operations inside stainless steel pipes.

A total of 23 employees were interviewed. The average tenure at Felker Brothers was 24 years (range: 6 months to 38 years). Seventeen of the 23 employees reported ever having work-related or work-aggravated health problems, mainly upper respiratory/mucous membrane irritation or musculoskeletal injury. Seven of the 23 employees reported current upper respiratory or mucous membrane irritation. All reported that these symptoms were not severe enough to keep them from working. Welding fumes, acid vapors from the pickling tank, general plant dust, and general plant ventilation could contribute to these symptoms. Twelve (52\%) of those interviewed were previous smokers, $6(26 \%)$ had never smoked, and $5(22 \%)$ were current smokers. There was no significant relationship between current mucous membrane irritation and smoking status. 
PBZ air samples indicated the potential for some workers to be exposed to nickel and $\mathrm{Cr}^{\mathrm{VI}}$ concentrations above the NIOSH REL and to manganese above the ACGIH ${ }^{\circledR}$ TLV ${ }^{\circledR}$. Although the potential for exposure to nickel and chromium exists, at the time of our evaluation, the types of cancers linked to exposure to these substances have not been reported among current or former employees of Felker Brothers. Welding fumes, acid vapors from the pickling tank, general plant dust, and general plant ventilation could contribute to irritant symptoms reported by some workers. Engineering controls (i.e., local exhaust ventilation) should be used in areas where sample results indicated exposures exceeding applicable occupational criteria. Other recommendations to reduce worker exposures are provided in the report.

Keywords: SIC 3317 (Steel Pipe and Tubes). stainless steel, nickel, chromium, pipe, tube, fittings, pre-fabricated piping systems, cutting, welding, grinding, fabricating, pickling. 


\section{TABLE OF CONTENTS}

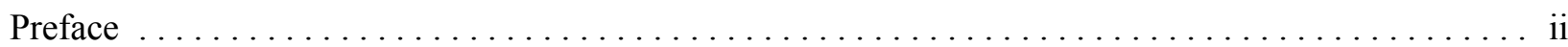

Acknowledgments and Availability of Report $\ldots \ldots \ldots \ldots \ldots \ldots \ldots \ldots \ldots \ldots \ldots \ldots$ ii

Highlights of the HHE Report $\ldots \ldots \ldots \ldots \ldots \ldots \ldots \ldots \ldots \ldots \ldots \ldots \ldots \ldots \ldots \ldots \ldots \ldots \ldots \ldots \ldots$



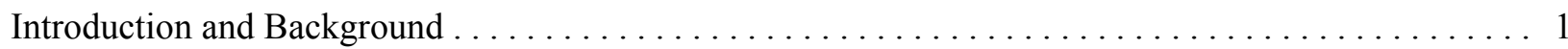

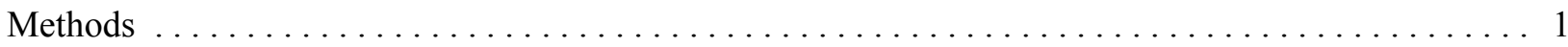

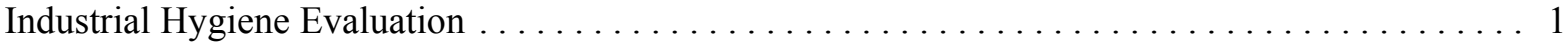

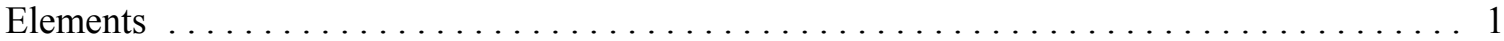

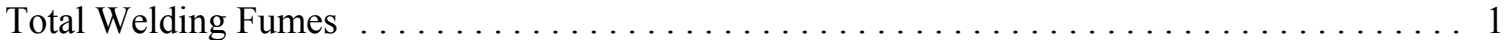

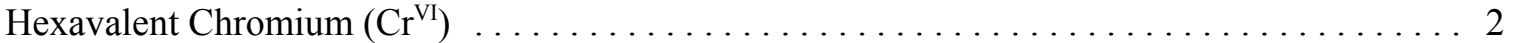

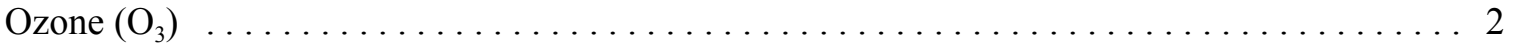

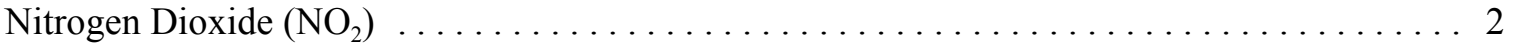

Carbon Monoxide (CO), Carbon Dioxide $\left(\mathrm{CO}_{2}\right)$, Temperature, and Relative Humidity . . . . . 2

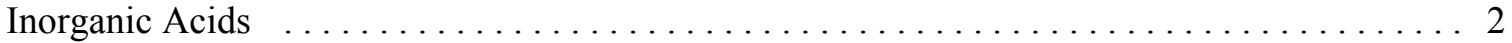

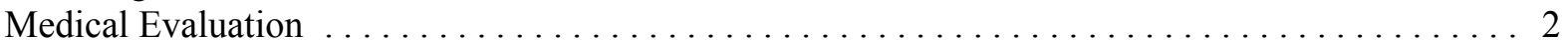

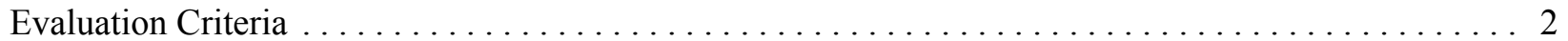

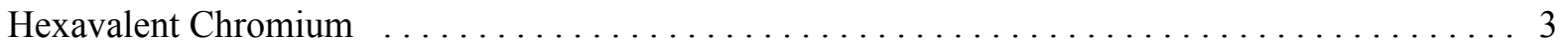

Nickel ....................................... 3

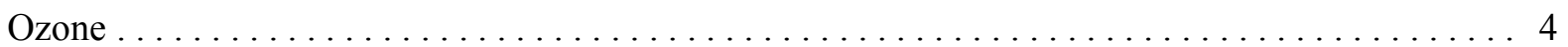

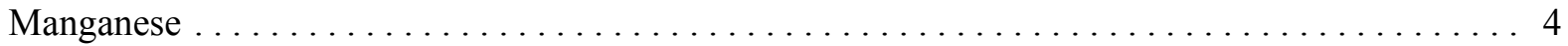

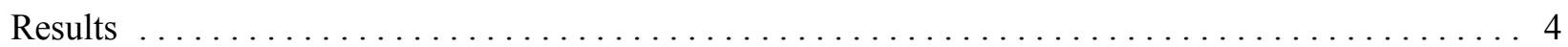

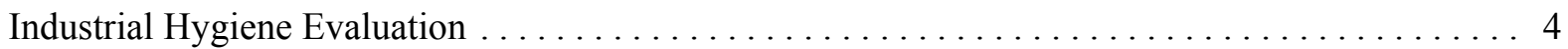

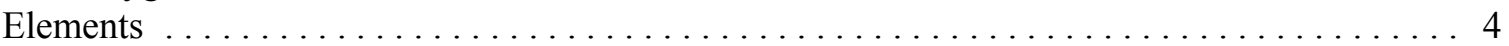

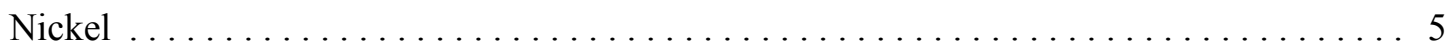

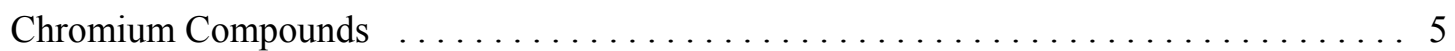

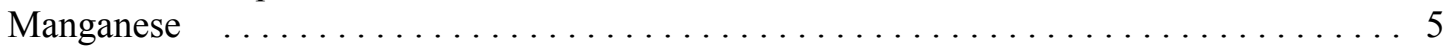

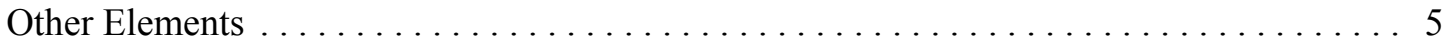

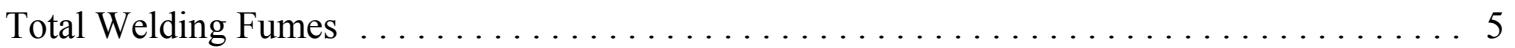

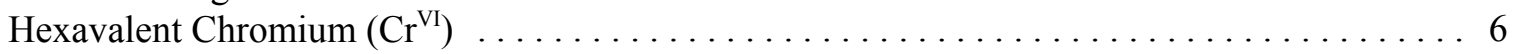

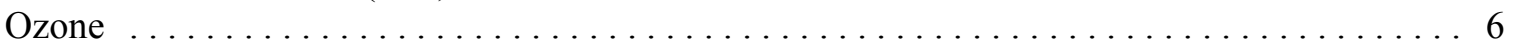

Carbon Monoxide, Nitrogen Dioxide, and Carbon Dioxide $\ldots \ldots \ldots \ldots \ldots \ldots \ldots \ldots$

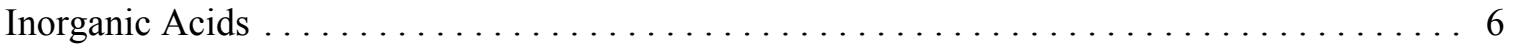

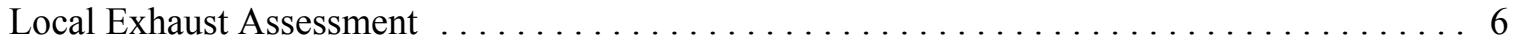

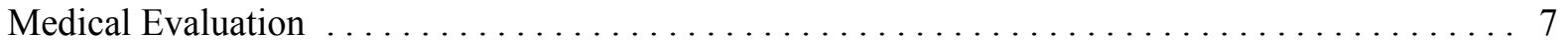

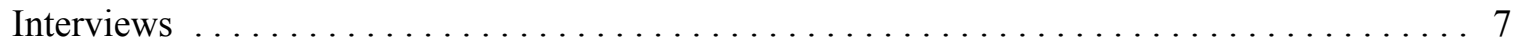

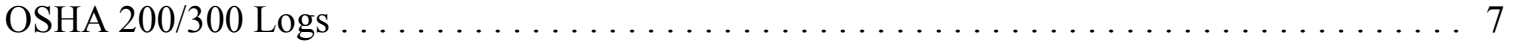

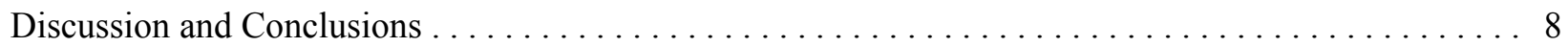

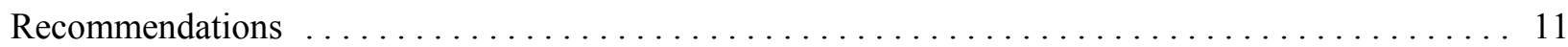

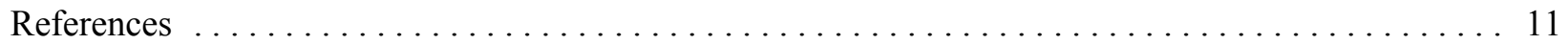




\section{INTRODUCTION AND BACKGROUND}

On December 23, 2002, the National Institute for Occupational Safety and Health (NIOSH) received a request from the International Brotherhood of Boiler makers regarding worker exposures to chromium and nickel compounds during the manufacturing of high quality, corrosive resistant stainless steel products and fabricated piping systems at the two Felker Brothers Corporation facilities in Marshfield, Wisconsin. Union officials also expressed concerns about potential carcinogenic effects of these exposures, although they reported being unaware of any current or former employees having been diagnosed with cancer.

Felker Brothers Corporation is a manufacturer of stainless steel commodity products (pipe, tube and fittings), and stainless steel custom products (pre-fabricated piping systems) with approximately 114 employees working in production areas of the two facilities. Manufacturing processes at the facilities include cutting, welding, grinding, fabricating, and pickling.

On February 5, 2003, NIOSH investigators made an initial site visit to gather information on stainless steel cutting, welding, and grinding processes. The opening conference was attended by management, union officials, and NIOSH representatives. An in-depth industrial hygiene evaluation was conducted at the two facilities (i.e., main and depot facilities) during May 28-29, 2003. Air sampling was conducted throughout the plant during stainless steel cutting, welding, and grinding operations. Air samples for inorganic acids were collected on workers involved in pickling and acid paste operations. In addition, temperature and humidity measurements were also collected.

A NIOSH physician interviewed 23 serially selected employees from approximately 114 production workers within the two facilities.
Private medical interviews covered employees tenure and department, past medical history, smoking history, and current symptoms, complaints, and concerns. A closing conference was held on May 29, 2003, during which preliminary findings and recommendations were discussed.

\section{METHODS}

\section{Industrial Hygiene Evaluation}

Personal breathing zone (PBZ) air sampling was conducted on various employees within the main and depot facilities during stainless steel cutting, welding, and grinding operations. PBZ and area air samples were collected for elements (various metal compounds including nickel and chromium), total welding fumes, hexavalent chromium $\left(\mathrm{Cr}^{\mathrm{VI}}\right)$, ozone $\left(\mathrm{O}_{3}\right)$, nitrogen dioxide $\left(\mathrm{NO}_{2}\right)$, carbon monoxide $(\mathrm{CO})$, carbon dioxide $\left(\mathrm{CO}_{2}\right)$, temperature, relative humidity, and inorganic acids.

\section{Elements}

PBZ air samples for elements were quantitatively analyzed for silver, aluminum, arsenic, beryllium, calcium, cadmium, cobalt, chromium, copper, iron, lithium, magnesium, manganese, molybdenum, sodium, nickel, phosphorus, lead, platinum, selenium, tellurium, thallium, titanium, vanadium, yttrium, zinc, and zirconium using a Perkin Elmer Optima 3000 DV inductively coupled plasma spectrometer according to NIOSH Method 7300. ${ }^{1}$ These samples were collected on 37-mm diameter (5- $\mu \mathrm{m}$ pore-size) polyvinyl chloride (PVC) filters, using sampling pumps calibrated at 2 liters per minute (Lpm).

\section{Total Welding Fumes}

PBZ air samples for total welding fumes were collected on 37-mm diameter (5- $\mu \mathrm{m}$ pore-size) PVC filters, using sampling pumps calibrated at 2 Lpm. Filters were gravimetrically analyzed (filter weight) according to NIOSH Method $0500{ }^{1}$ 


\section{Hexavalent Chromium $\left(\mathrm{Cr}^{\mathrm{VI}}\right)$}

PBZ air samples for $\mathrm{Cr}^{\mathrm{VI}}$ were collected on $37-\mathrm{mm}$ diameter $(5-\mu \mathrm{m}$ pore-size) PVC filters, using sampling pumps calibrated at $2 \mathrm{Lpm}$. These samples were analyzed by high performance liquid chromatography (HPLC) according to NIOSH method $7605 .^{1}$

\section{Ozone $\left(\mathrm{O}_{3}\right)$}

Area monitoring for $\mathrm{O}_{3}$ was conducted with colorimetric detector tubes (Draeger $0.05 / \mathrm{b}$, \#6733181 - range 0.05 to 0.7 parts per million [ppm] with 10 strokes on the pump) in the breathing zone of workers during welding activities. The detector tubes are used by drawing air through the tube with a bellows-type pump. The resulting length of the stain in the tube (produced by a chemical reaction with the sorbent) is proportional to the concentration of the air contaminant.

\section{Nitrogen Dioxide $\left(\mathrm{NO}_{2}\right)$}

Area monitoring for $\mathrm{NO}_{2}$ was conducted with colorimetric detector tubes (Draeger 0.05/c, \#CH30001 - range 0.5 to $10 \mathrm{ppm}$ with 5 strokes on the pump) in the breathing zone of workers during welding.

\section{Carbon Monoxide (CO), Carbon Dioxide $\left(\mathrm{CO}_{2}\right)$, Temperature, and Relative Humidity}

Area real-time $\mathrm{CO}, \mathrm{CO}_{2}$, temperature, and relative humidity spot measurements were taken using a hand-held, battery operated, TSI Q-Track ${ }^{\mathrm{TM}}$ (Model 8554) indoor air quality (IAQ) monitor in the breathing zone of workers during welding operations. This portable monitor uses an Electrochemical sensor to measure $\mathrm{CO}$ in the range of 0 $500 \mathrm{ppm}$. The monitor uses a non-dispersive infrared absorption (NDIR) sensor to measure $\mathrm{CO}_{2}$ in the range of $0-5000 \mathrm{ppm}$. In addition, the monitor is capable of measuring temperature in the range of 32 to 122 degrees Fahrenheit, and is also able to measure relative humidity in the range of 5 to $95 \%$.

\section{Inorganic Acids}

PBZ air samples for inorganic acids (i.e., hydrofluoric, hydrochloric, nitric, phosphoric, sulfuric, and hydrobromic acid) were collected on solid sorbent tubes (washed silica gel, 400 milligrams $[\mathrm{mg}] / 200 \mathrm{mg}$ with glass fiber plug) attached by tubing to sampling pumps calibrated at a flow rate of $0.2 \mathrm{Lpm}$. The samples were analyzed for fluoride, chloride, nitrate, phosphate, bromide, and sulfate ion concentrations by ion chromatography according to NIOSH sampling method 7903. ${ }^{1}$ The ion results were then converted to the respective acid.

\section{Medical Evaluation}

Twenty-five employees were serially selected for interviews from approximately 114 production employees at both the main and depot facilities. Information regarding current or former employees with cancer was solicited from these interviews and from the union and management. The Illness and Injury reports (Occupational Safety and Health Administration 200/300 logs) from the past five years were reviewed.

\section{EVALUATION CRITERIA}

As a guide to the evaluation of the hazards posed by workplace exposures, NIOSH field staff employ environmental evaluation criteria for the assessment of a number of chemical and physical agents. These criteria are intended to suggest levels of exposure to which most workers may be exposed up to 10 hours per day, 40 hours per week for a working lifetime without experiencing adverse health effects. It is, however, important to note that not all workers will be protected from adverse health effects even though their exposures are maintained below these levels. A small percentage may experience adverse health effects because of individual susceptibility, a pre-existing medical condition, and/or a hypersensitivity (allergy). In addition, some hazardous substances may act in combination with other workplace exposures, the general environment, or with medications or personal habits of the worker to 
produce health effects even if the occupational exposures are controlled at the level set by the criterion. These combined effects are often not considered in the evaluation criteria. Also, some substances are absorbed by direct contact with the skin and mucous membranes, and thus potentially increases the overall exposure. Finally, evaluation criteria may change over the years as new information on the toxic effects of an agent become available.

The primary sources of environmental evaluation criteria for the workplace are: (1) NIOSH Recommended Exposure Limits (RELs), ${ }^{2}$ (2) the American Conference of Governmental Industrial Hygienists' (ACGIH ${ }^{\circledR}$ ) Threshold Limit Values (TLVs $\left.{ }^{\circledR}\right),{ }^{3}$ and (3) the U.S. Department of Labor, OSHA Permissible Exposure Limits (PELs). ${ }^{4}$ Employers are encouraged to follow the OSHA limits, the NIOSH RELs, the ACGIH TLVs, or whichever are the more protective criterion.

OSHA requires an employer to furnish employees a place of employment that is free from recognized hazards that are causing or are likely to cause death or serious physical harm [Occupational Safety and Health Act of 1970, Public Law 91-596, sec. 5.(a)(1)]. Thus, employers should understand that not all hazardous chemicals have specific OSHA exposure limits such as PELs and short-term exposure limits (STELs). An employer is still required by OSHA to protect their employees from hazards, even in the absence of a specific OSHA PEL.

A time-weighted average (TWA) exposure refers to the average airborne concentration of a substance during a normal workday. Some substances have recommended STEL or ceiling values which are intended to supplement the TWA where there are recognized toxic effects from higher exposures over the short-term.

\section{Hexavalent Chromium}

The toxicity and solubility of chromium compounds that contain chromium in the $\mathrm{Cr} 2+$, $\mathrm{Cr} 3+$, or $\mathrm{Cr}^{\mathrm{VI}}$ valence state vary greatly, but those that contain $\mathrm{Cr}^{\mathrm{VI}}$ are of the greatest health concern. $\mathrm{Cr}^{\mathrm{VI}}$ compounds include lead chromate and zinc chromate pigments, chromic acid, and soluble compounds such as those used in chromium plating. Some $\mathrm{Cr}^{\mathrm{VI}}$ compounds are severe irritants of the respiratory tract and skin, and some (including chromates) have been found to cause lung cancer in exposed workers. ${ }^{5}$ Allergic dermatitis is one of the most common effects of chromium toxicity among exposed workers.

NIOSH has identified $\mathrm{Cr}^{\mathrm{VI}}$ as a potential occupational carcinogen. The NIOSH REL for $\mathrm{Cr}^{\mathrm{VI}}$, based on a designation as a potential occupational carcinogen, is 0.001 milligram per cubic meter $\left(\mathrm{mg} / \mathrm{m}^{3}\right)$ full shift TWA. ${ }^{2}$ The OSHA PEL for $\mathrm{Cr}^{\mathrm{VI}}$ is a ceiling limit of $0.1 \mathrm{mg} / \mathrm{m}^{3},{ }^{6}$ and the ACGIH TLV is $0.01 \mathrm{mg} / \mathrm{m}^{3}$ for insoluble $\mathrm{Cr}^{\mathrm{VI}}$ compounds and $0.05 \mathrm{mg} / \mathrm{m}^{3}$ for soluble $\mathrm{Cr}^{\mathrm{VI}}$ compounds. $^{3} \quad$ Nonoccupational sources of exposure to chromium may include cigarette smoke.

\section{Nickel}

Metallic nickel compounds cause allergic contact dermatitis. ${ }^{5}$ NIOSH considers nickel a potential occupational carcinogen, as nickel refining has been associated with an increased risk of nasal and lung cancer. ${ }^{6}$ Cigarette smoking may also be a nonoccupational source of exposure to nickel compounds. ${ }^{7}$ The NIOSH REL for nickel, based on the designation as a potential occupational carcinogen, is $0.015 \mathrm{mg} / \mathrm{m}^{3}{ }^{2}$ The ACGIH TLV for insoluble compounds of nickel (i.e., nickel oxides $^{8}$ ) is $0.2 \mathrm{mg} / \mathrm{m}^{3}$ (inhalable fraction), for soluble nickel compounds (i.e., nickel compounds that include chloride, sulfate, and nitrate ${ }^{8}$ ) the TLV is $0.1 \mathrm{mg} / \mathrm{m}^{3}$ (inhalable fraction), and the TLV for elemental nickel is $1.5 \mathrm{mg} / \mathrm{m}^{3}$ (inhalable fraction). ${ }^{3}$ The OSHA PEL for nickel is $1 \mathrm{mg} / \mathrm{m}^{3}{ }^{4}$

\section{Ozone}

Low concentrations of $\mathrm{O}_{3}(0.01 \mathrm{ppm}$ to $0.05 \mathrm{ppm})$ may produce a sharp, irritating odor even during brief exposures. ${ }^{9}$ Symptoms of ozone exposure include irritation of the eyes, dryness of the nose and throat, and cough. At higher ozone 
concentrations, more severe symptoms may develop. These symptoms may include headache, pain or tightness in the chest, and shortness of breath or tiredness. ${ }^{9}$ Short-term exposure (a few hours) to $\mathrm{O}_{3}$ concentrations on the order of 0.1 ppm has been shown to produce temporary decreases in measured lung volumes in humans. ${ }^{10}$

The NIOSH REL for $\mathrm{O}_{3}$ is $0.1 \mathrm{ppm}$ and is to be measured as a ceiling limit. ${ }^{2}$ A ceiling limit is a peak concentration that should not be exceeded at any time during the workday. NIOSH has also recommended an immediately dangerous to life and health (IDLH) limit of $5 \mathrm{ppm}$ for $\mathrm{O}_{3}{ }^{6}$ The current OSHA PEL for $\mathrm{O}_{3}$ is $0.1 \mathrm{ppm}$ for an 8-hour (40-hour work week) TWA. ${ }^{4}$ The current ACGIH TLV is based on the amount of physical exertion or work load required for the job being accomplished and is to be average over an 8-hour period. The TLV is $0.1 \mathrm{ppm}$ for jobs requiring light physical exertion, $0.08 \mathrm{ppm}$ for moderate physical exertion, $0.05 \mathrm{ppm}$ for heavy physical exertion, and $0.2 \mathrm{ppm}$ for heavy, moderate, or light work loads less than or equal to 2 hours in duration. ${ }^{3}$

\section{Manganese}

Manganese (Mn) is an abundant and ubiquitous element present throughout the environment including soil, water, air, vegetation, and food items. Manganese is an essential trace element necessary for the formation of connective tissue and bone as well as the metabolism of carbohydrates and lipids; for these reasons, adult humans require 2 to 3 milligrams $(\mathrm{mg})$ of dietary Mn per day. ${ }^{11}$ There are many important industrial uses for $\mathrm{Mn}$; it is used in the metal alloy industries, in ceramic and glass products, in rubber and wood preservatives; and in dry-cell batteries. ${ }^{5}$ The health effects of excessive occupational Mn exposure are primarily neurological and respiratory (including irritation, pneumonitis, and chronic bronchitis). Metal fume fever has also been reported with exposure to Mn fume. Most notably, occupational exposure to $\mathrm{Mn}$ dust is known to cause manganism, a Parkinsonian-like syndrome. This condition has also been referred to as Mn poisoning and chronic Mn toxicity.
Chronic Mn toxicity has been found in workers exposed to Mn during operations in which high concentrations of dust or fume were generated. Such operations have included mining, ore processing, purification processes, metallurgical and manufacturing processes, and welding of $\mathrm{Mn}$ alloys or use of welding rods containing $\mathrm{Mn}^{12}$ Inhalation is the primary route of occupational exposure, but most inhaled Mn dust is mobilized from the lungs and swallowed. ${ }^{13}$ Thus, the gastrointestinal tract may be an important route of absorption for inhaled as well as ingested Mn dust.

The NIOSH REL for Mn compounds is $1 \mathrm{mg} / \mathrm{m}^{3}$ (full shift TWA), with a STEL of $3.0 \mathrm{mg} / \mathrm{m}^{3}$ based on central nervous system effects and pneumonitis. ${ }^{14,2}$ The OSHA PEL for manganese is a ceiling criteria of $5.0 \mathrm{mg} / \mathrm{m}^{3}{ }^{4}$ The ACGIH current TLV for manganese is $0.2 \mathrm{mg} / \mathrm{m}^{3}{ }^{3}$

\section{RESULTS}

\section{Industrial Hygiene Evaluation}

\section{Elements}

A total of 44 PBZ air samples for elements were collected throughout the main and depot facilities. These samples were analyzed for silver, aluminum, arsenic, beryllium, calcium, cadmium, cobalt, chromium, copper, iron, lithium, magnesium, manganese, molybdenum, sodium, nickel, phosphorus, lead, platinum, selenium, tellurium, thallium, titanium, vanadium, yttrium, zinc, and zirconium.

\section{Nickel}

PBZ air samples with nickel concentrations equal to or above the NIOSH REL of $0.015 \mathrm{mg} / \mathrm{m}^{3}$ are listed in Table 1. All other nickel samples (not listed in Table 1) collected in the main and depot facilities indicated nickel concentrations less than occupational criteria (NIOSH, ACGIH, and OSHA).

Four of the highest concentrations of nickel were on workers in the main facility. Two of these 
workers were performing welding/grinding operations inside large stainless steel pipes (department 206). The PBZ samples collected on these workers indicated nickel TWA exposures of $0.12 \mathrm{mg} / \mathrm{m}^{3}$ and $0.15 \mathrm{mg} / \mathrm{m}^{3}$. One worker had a nickel TWA exposure of $0.16 \mathrm{mg} / \mathrm{m}^{3}$ while welding fins on the outside of a large stainless steel pipe in department 206, and another worker had a nickel TWA exposure of $0.16 \mathrm{mg} / \mathrm{m}^{3}$ while performing tasks as a fabricator in the main facility.

One PBZ sample collected on a worker in the depot facility while performing welding operations on stainless steel indicated a concentration of $0.0197 \mathrm{mg} / \mathrm{m}^{3}$, which is above the NIOSH REL. The worker that this sample was collected on consistently smoked in the shop during the work shift. Smoking may also be a nonoccupational source of exposure to nickel compounds. ${ }^{7}$ All other PBZ samples collected on workers in the depot facility indicated concentrations of nickel below applicable occupational criteria. All PBZ samples collected and analyzed for nickel had concentrations below the OSHA PEL of $1 \mathrm{mg} / \mathrm{m}^{3}$.

\section{Chromium Compounds}

All PBZ air samples for chromium compounds had concentrations below applicable occupational exposure criteria (i.e., NIOSH REL of $0.5 \mathrm{mg} / \mathrm{m}^{3}$, ACGIH ${ }^{\circledR}$ TLV ${ }^{\circledR}$ of $0.5 \mathrm{mg} / \mathrm{m}^{3}$, and OSHA PEL of $0.5 \mathrm{mg} / \mathrm{m}^{3}$ ). Chromium concentrations for those samples that had nickel concentrations above the REL are listed in Table 1. These samples represent some of the more elevated chromium concentrations at the facility. Workers with the highest reported TWA chromium exposures were located in department 206 where two of these workers were welding/grinding inside large stainless steel pipes $\left(0.26 \mathrm{mg} / \mathrm{m}^{3}\right.$ and $\left.0.36 \mathrm{mg} / \mathrm{m}^{3}\right)$, and one worker welded fins on a large stainless steel pipe $\left(0.36 \mathrm{mg} / \mathrm{m}^{3}\right)$. A worker performing tasks as a fabricator in the main facility had a chromium compound TWA exposure of 0.24 $\mathrm{mg} / \mathrm{m}^{3}$.

\section{Manganese}

PBZ air sample results for three workers in department 206 indicated concentrations exceeding the ACGIH TLV of $0.2 \mathrm{mg} / \mathrm{m}^{3}$ for manganese (see Table 1). Two of these workers were welding/grinding inside large stainless steel pipes and had PBZ TWA manganese concentrations of $0.34 \mathrm{mg} / \mathrm{m}^{3}$ and $0.32 \mathrm{mg} / \mathrm{m}^{3}$. The manganese TWA concentration for another worker was $0.31 \mathrm{mg} / \mathrm{m}^{3}$ while welding/grinding fins on large stainless steel pipes. These concentrations are below the NIOSH REL of 1 $\mathrm{mg} / \mathrm{m}^{3}$. All other manganese samples were below applicable occupational criteria.

\section{Other Elements}

Results of sampling for all other element compounds analyzed by NIOSH method 7300 indicated concentrations below applicable occupational exposure criteria.

\section{Total Welding Fumes}

A total of 44 PBZ air samples were collected and gravimetrically analyzed for total welding fumes on workers throughout the main and depot facilities. These samples were also analyzed for elements to get a breakdown of the different elemental compounds and concentrations. One PBZ sample indicated a total welding fume concentration of $5.2 \mathrm{mg} / \mathrm{m}^{3}$ which exceeds the ACGIH TLV of $5 \mathrm{mg} / \mathrm{m}^{3}$. However, this sample was collected on a worker who performed grinding operations in addition to operations where he may have been exposed to welding fumes. Therefore, this sample is representative of both grinding dust and welding fumes. The element results for this sample indicated that concentrations of the various metal compounds were below applicable occupational exposure criteria, with the exception of nickel, which was present at a concentration of $0.04 \mathrm{mg} / \mathrm{m}^{3}$ (above the NIOSH REL of $0.015 \mathrm{mg} / \mathrm{m}^{3}$ ). All other PBZ air samples for total welding fumes were below the ACGIH TLV (5 mg/m $\mathrm{m}^{3}$ for total welding fume).

\section{Hexavalent Chromium $\left(\mathrm{Cr}^{\mathrm{VI}}\right)$}


A total of $46 \mathrm{Cr}^{\mathrm{VI}} \mathrm{PBZ}$ air samples were collected in the main and depot facilities. Table 2 list $\mathrm{Cr}^{\mathrm{VI}}$ PBZ air sample results exceeding the NIOSH REL of $0.001 \mathrm{mg} / \mathrm{m}^{3}$. All other $\mathrm{Cr}^{\mathrm{VI}} \mathrm{PBZ}$ air samples collected at both facilities (not listed on Table 2) indicated concentrations below applicable occupational exposure criteria.

The two highest PBZ air sampling results were taken on workers in department 206. PBZ samples for a worker who performed work tasks such as welding/grinding inside large stainless steel pipes and another worker who welded fins on large stainless steel pipes both indicated $\mathrm{Cr}^{\mathrm{VI}}$ concentrations of $0.02 \mathrm{mg} / \mathrm{m}^{3}$, which exceeds the ACGIH TLV $\left(0.01 \mathrm{mg} / \mathrm{m}^{3}\right)$ for insoluble $\mathrm{Cr}^{\mathrm{VI}}$ compounds.

\section{Ozone}

$\mathrm{O}_{3}$ samples were collected in the breathing zone of workers during welding operations. Concentrations of $0.13 \mathrm{ppm}$ and $0.59 \mathrm{ppm}$ were detected near a worker welding inside large stainless steel pipes in department 206. These results exceed the NIOSH REL (Ceiling limit of $0.1 \mathrm{ppm}$ ), and indicate a potential to exceed the ACGIH TLVs (8-hour TWA of $0.1 \mathrm{ppm}$ for light work, $0.08 \mathrm{ppm}$ for moderate work, $0.05 \mathrm{ppm}$ for heavy work, and $0.2 \mathrm{ppm}$ for heavy, moderate, or light work loads less than or equal to 2 hours in duration) and OSHA PEL (8-hour TWA of 0.1 $\mathrm{ppm}$ ) if continuous welding is done inside the pipe throughout the work shift. All other $\mathrm{O}_{3}$ samples collected throughout the main and depot facilities had concentrations below applicable occupational exposure criteria.

Carbon Monoxide, Nitrogen Dioxide, and Carbon Dioxide

Instantaneous real-time samples collected for $\mathrm{CO}$, $\mathrm{NO}_{2}$, and $\mathrm{CO}_{2}$ near the breathing zone of workers while performing welding operations, indicated concentrations well below applicable occupational exposure criteria.

Inorganic Acids
Inorganic acid samples were collected in the breathing zone of workers during pickling operations in the main facility at the pickling tank, and pickle paste operations in both the main and depot facilities. Nitric acid concentrations were in the range of 0.008 to $0.094 \mathrm{ppm}$, hydrochloric acid concentrations in the range of 0.0045 to 0.026 ppm, sulfuric acid concentrations in the range of 0.0002 to $0.002 \mathrm{ppm}$, and hydrofluoric acid concentrations in the range of 0.1 to $0.87 \mathrm{ppm}$. These results indicate that inorganic acid concentrations were below applicable occupational exposure criteria. Hydrobromic and phosphoric acids were not detected on our samples.

\section{Local Exhaust Assessment}

The big plasma cutting table was not equipped with a local exhaust ventilation (LEV) system during the time of our evaluation. This table was located in an area of the main facility near one of the two fixed dilution ventilation systems in the shop. The dilution ventilation systems in the shop provided approximately $20 \%$ outside air and $80 \%$ recirculated air from the shop. They maintained the shop under positive pressure and were equipped with filters that filtered the air before resupplying it back into the shop.

The facility had LEV for plasma cutting operations on the cybermation table and elbow cut-off station. The ventilation measurements collected on the downdraft ventilation system at the cybermation table indicated a velocity of 76 feet per minute (fpm) at the face and $55 \mathrm{fpm}$ at approximately 6-8 inches above the face. The area of the cybermation table was approximately 53 square feet $\left(\mathrm{ft}^{2}\right)$ and the volume of air moved (based upon the area and our face velocity measurements) was 4028 cubic feet per minute $\left(\mathrm{ft}^{3} / \mathrm{min}\right)$. Observations during work activities and smoke powder test indicated that fume generated from cutting operations on this table may escape the capture of the hood. During our survey, considerable amounts of slag material from the cutting operations was located in the bottom of the 
downdraft hood and may have resulted in reduced air flow through the system.

The elbow cut-off station had two hoods located near the elbow cutting operation. The ventilation duct located directly under the cutting operation had an area of $0.11 \mathrm{ft}^{2}$ and an average face velocity of $209 \mathrm{fpm}$, which produces a calculated volumetric air flow of $23 \mathrm{ft}^{3} / \mathrm{min}$. The rectangular hood located off to the side of the cutting operation had an area of $0.125 \mathrm{ft}^{2}$ and a face velocity of $780 \mathrm{fpm}$, which produces a calculated volumetric air flow of $97.5 \mathrm{ft}^{3} / \mathrm{min}$. Observations during normal work activities and smoke powder testing indicated that the elbow cut-off ventilation system effectively controlled fume emissions.

A ventilation system located inside the grinding booth was also evaluated during our survey. This system consisted of flexible duct attached to two small hoods. The flexible duct was connected to a fan mounted on top of a 55-gallon drum inside the grinding booth. The system appeared to be designed to capture the large metal particles generated during grinding activities. However, our observations and smoke test indicated that small aerosols captured by the system were blown out the top of the drum and into the work area. Therefore, this system did not appear to be effective.

\section{Medical Evaluation}

\section{Interviews}

Twenty-five employees were serially selected for interviews from approximately 114 production employees at both the $4^{\text {th }}$ street (main facility) and depot street facilities. One of those selected was off work on the days of the interviews and two declined to be interviewed. One of those who declined was replaced, therefore a total of 23 employees were interviewed. Nineteen $(83 \%)$ were from the 4th street facility and four (17\%) were from the depot street facility. The majority of employees (about 70\%) work at the 4th Street facility and the processes and exposures are similar at both sites. The average age of those interviewed was 52 years (range: 30 to 62 years). The average length of time these employees had worked at Felker Brothers was 24 years (range: 6 months to 38 years). Five were described as machine operators, five as utility, four as fabrication/fitter, three as welder, three as semiskilled, and three as either maintenance, patternmaker, or tool builder. Seventeen of the 23 employees reported ever having work-related or work-aggravated health problems, mainly upper respiratory/mucous membrane irritation or musculoskeletal injury. Seven of the 23 employees reported current upper respiratory or mucous membrane irritation. All reported that these symptoms were not severe enough to keep them from working. Twelve $(52 \%)$ of those interviewed were previous smokers, six $(26 \%)$ had never smoked, and five (22\%) were current smokers. There was no significant relationship between current mucous membrane irritation and smoking status. Interviewed employees were not aware of current or former employees with cancer. Union officials reported that nine retirees may have had cancer, but were unable to provide details about the type of cancer, time of diagnosis, or job history.

\section{OSHA 200/300 Logs}

The OSHA logs from January 1998 through December 2002 were reviewed. There were 71, $47,30,24$, and 29 recorded injury or illness entries for the years 1998 through 2002, respectively. These totals are for both facilities. The majority of entries were for strains, contusions, lacerations, and foreign body to eye. There was only one entry for mucous membrane irritation; it occurred in 1998.

\section{DiscussiON AND CONCLUSIONS}

PBZ air samples collected during our evaluation indicated the potential for some workers to be exposed to nickel and $\mathrm{Cr}^{\mathrm{VI}}$ at concentrations above the NIOSH REL (see Tables 1 and 2), and to Mn 
above the ACGIH TLV (see Table 1). The PBZ results indicated that the highest concentrations of nickel, $\mathrm{Mn}$, and $\mathrm{Cr}^{\mathrm{VI}}$ occurred during operations in department 206 where workers welded inside large stainless steel pipes or welded fins on a large stainless steel pipe. Two detector tube results for $\mathrm{O}_{3}$ also indicated concentrations exceeding the NIOSH REL ceiling limit and the potential to exceed ACGIH and OSHA occupational criteria (if consistent welding is accomplished throughout the work shift) during welding operations inside stainless steel pipes in department 206.

Engineering controls (i.e.,LEV) should be used in areas where sample results indicated concentrations exceeding applicable occupational criteria. Portable air cleaning systems are commercially available for the collection and filtration of welding fumes. However, these systems require stringent maintenance to ensure that they are operating at manufacturer specifications to effectively remove the aerosols generated during cutting or welding operations. If these systems are not maintained properly or are not performing to manufacturer's specifications they may release welding aerosols back into the work environment. The ACGIH ventilation manual recommends avoiding recirculating filtered air from welding hoods back into occupied spaces unless the welding is low hazard and produces low quantities of contaminants. ${ }^{15}$ Because nickel and $\mathrm{Cr}^{\mathrm{VI}}$ compounds are considered potential occupational carcinogens the use of systems that re-circulate filtered air back into work areas is not recommended.

The filters on the dilution ventilation systems in the main facility may not be effective for removing fumes generated during welding activities inside the shop without the use of high efficiency particulate air filters (HEPA) and appropriate seals. Also, these systems are not effective for reducing emissions at the source of the welding operations in the shop.

LEV is the best way to remove fumes at the source of the operation. A welding ventilation movable exhaust hood system could be used to capture the contaminants generated during welding operations. The local exhaust ventilation system should be designed to have a capture velocity (minimum hood-induced air velocity necessary to capture and convey the contaminant into the hood) of approximately 100 - $170 \mathrm{fpm}$ with the higher values used for poor conditions such as high crossdraft velocities and with higher hazard levels. ${ }^{15}$ The system should also have a minimum duct velocity of approximately $3000 \mathrm{fpm}$ (welding ventilation movable exhaust hoods Figure VS-9002, ACGIH Ventilation Manual). ${ }^{15}$ The hood of the local exhaust ventilation system should be placed as close as possible to the source of contaminant generation. However, it should be noted that capture velocities above 100-200 fpm may disturb shield gas. ${ }^{15}$ Anytime LEV is used in a facility, sufficient clean make-up air must be provided to the shop for the systems to operate effectively. Depending on the climate, the temperature of the make-up air supplied to the shop may need to be considered.

Additional methods that could be used to control worker exposures in areas where sample results indicate concentrations exceeding applicable exposure criteria consist of administrative controls and personal protective equipment (PPE) (i.e., respirators). Administrative controls and PPE are designed to protect workers from airborne exposures while engineering controls are being implemented or when engineering controls are not feasible or effective in reducing air contaminants to acceptable levels. For respirators to be worn by employees, an appropriate respiratory protection program must be utilized by the company and be in accordance with OSHA regulation 29 CFR 1910.134. ${ }^{16}$ Under the NIOSH respirator use policy for protection against carcinogens, NIOSH recommends respirators based on the following selection criterion:

\section{Assigned protection factor $(A P F)>$ (workplace airborne concentration/NIOSH REL)}

This selection criteria only applies to respirators used in a proper respirator program under the supervision of a properly trained respirator program administrator. Respirators used without 
such a program with all its essential elements can not be relied upon to protect workers. ${ }^{17}$

Each worker required to wear a respirator must be medically evaluated and cleared by a physician to wear the specific respirator before performing assigned tasks. For respirators to be effective and protect workers from harmful exposures they must be selected, inspected, and maintained properly. Respirators should be inspected by the worker prior to and after each use for any defects. Respiratory protective equipment should also be cleaned and disinfected after each use. Respiratory protective devices should never be worn when a satisfactory face seal can not be obtained. Many conditions may prevent a good seal between the worker's face and the respirator. Some of these conditions include facial hair, glasses, or an unusually structured face. All workers required to wear a respirator must be properly trained on the selection, use, limitations, and maintenance of the respirator and also be fit-tested to assure a proper seal between the workers face and the respirator prior to performing work tasks in a contaminated area. A recent article [Campbell, D.L. et al. 2001], recommends to purchase only respirators with good fitting characteristics $(\mathrm{h} \geq 0.95)$ and then carefully conduct fit-test on individual workers. ${ }^{18}$ All workers should receive annual fit-testing with a quantitative testing device. When not in use, respirators must be stored in a clean environment located away from any source of contamination.

During our evaluation, we observed workers eating, drinking, and smoking in the production areas of the plant. These activities should be restricted to designated areas away from contaminants in the shop to reduce potential secondary exposures. Additionally, workers should also change out of contaminated clothing and wash thoroughly to remove any contaminants prior to eating, drinking, smoking, or leaving work (to prevent any possible contamination of vehicles or homes). Housekeeping practices could also be improved to reduce secondary exposures to contaminants. Dry-sweeping in the facilities should be prohibited to prevent dust from becoming airborne which would increase workers' exposures. Only wet clean-up methods (i.e., mopping) or vacuuming with an approved HEPA filter vacuum should be used during clean-up activities. Wet clean-up methods should not be used in any area where they may cause a potential electrical or safety hazard.

The plant currently has a safety/ergonomics team which consist of management and worker representatives. This team has scheduled meetings to address health and safety issues within the workplace. We encourage the exchange of concerns and communication between management officials and worker representatives on this team. Employees should be made aware of workplace health and safety concerns and decisions made by facility managers to address those concerns. Any employees with work-related health concerns should be encouraged to report these concerns to the safety/ergonomics team representatives.

During our evaluation, NIOSH representatives observed workers loading stainless steel pipes on a truck at a distance of approximately 10-14 feet off the ground without fall protection. OSHA regulation 1910.23 C)(1) states "every open-sided floor or platform 4 feet or more above adjacent floor or ground level shall be guarded by a standard railing (or the equivalent as specified in paragraph (e)(3) of this section) on all open sides except where there is entrance to a ramp, stairway, or fixed ladder." 19

Seven of $23(30 \%)$ interviewed employees reported current upper respiratory or mucous membrane irritation related to work. Welding fumes, acid vapors from the pickling tank, general plant dust, and general plant ventilation could contribute to these symptoms.

While we did not receive any specific information to suggest that there is an excess of cancer among current or former employees at Felker Brothers, some general information on cancer and how we look at cancer in workplaces is provided in the following paragraphs. 
Cancer is a group of different diseases that have the same feature, the uncontrolled growth and spread of abnormal cells. Each different type of cancer may have its own set of causes. Cancer is common in the United States. One of every four deaths in the United States is from cancer. Among adults, cancer is more frequent among men than women, and is more frequent with increasing age. Many factors play a role in the development of cancer. The importance of these factors is different for different types of cancer. Most cancers are caused by a combination of several factors. Some of the factors include: (a) personal characteristics such as age, sex, and race, (b) family history of cancer, (C) diet, (d) personal habits such as cigarette smoking and alcohol consumption, (e) the presence of certain medical conditions, (f) exposure to cancer-causing agents in the environment, and (g) exposure to cancer-causing agents in the workplace. In many cases, these factors may act together or in sequence to cause cancer. Although some causes of some types of cancer are known, we don't know everything about the causes of cancer.

When cancer in a workplace is described, it is important to learn whether the type of cancer is a primary cancer or a metastasis (spread of the primary cancer into other organs). Only primary cancers are used to investigate cancers.

Because cancer is a common disease, cancer can be found among people at any workplace. In the United States, one in two men and one in three women will develop cancer over the course of their lifetimes. These figures show the unfortunate reality that cancer occurs more often than many people realize. When several cases of cancer occur in a workplace they may be part of a true cluster when the number is greater than we expect compared to other groups of people similar with regard to age, sex, and race. Disease or tumor rates, however, are highly variable in small populations and rarely match the overall rate for a larger area, such as the state, so that for any given time period some populations have rates above the overall rate and other have rates below the overall rate. So, even when there is an excess, this may be completely consistent with the expected random variability. In addition, calculations like this make many assumptions, which may not be appropriate for every workplace. Comparing rates without adjusting for age, sex, or other population characteristics assumes that such characteristics are the same in the workplace as in the larger population, which may not be true.

The relationship between some agents and certain cancers has been well established. For other agents and cancers, there is a suspicion but the evidence is not definitive. When a known or suspected cancer-causing agent is present and the types of cancer occurring have been linked with these exposures in other settings, we are more likely to make the connection between cancer and a workplace exposure. Although the potential for exposure to nickel and chromium exists, at the time of our evaluation the types of cancers linked to exposure to these substances (i.e., lung and nasal $)^{20,21}$, have not been reported among current or former employees of Felker Brothers.

The time between first exposure to a cancer-causing agent and clinical recognition of the disease is called the latency period. Latency periods vary by cancer type, but usually are 15 to 20 years, or longer. For example, it can take up to 30 years after exposure to asbestos for mesothelioma to develop. This means that past exposures, which can be very difficult to assess, are more relevant to current cancer cases than are current exposures.

\section{RECOMMENDATIONS}

1. The highest exposures occurred during welding operations inside stainless steel pipes, and when welding fins on stainless steel pipes in department 
206. Local exhaust ventilation systems to control worker exposures should be a priority for these operations. A welding ventilation movable exhaust hood system could be used to capture the contaminants generated during welding operations.

Other recommendations for possible LEV systems to control emissions from welding and cutting operations are provided in the ACGIH Ventilation Manual (pages 10-148 through 10-154). ${ }^{15}$ Any ventilation system must be designed to meet fire, safety, or environmental codes that apply to this facility and operations.

2. Frequent maintenance should be performed on a regular basis to remove material that accumulates in the cybermation downdraft hood. Personal monitoring should be conducted to characterize worker exposures during the maintenance activities. Personnel performing these maintenance operations should be provided with appropriate controls or personal protection equipment to protect them from exposures.

3. After engineering controls have been installed, worker exposures should be re-evaluated to determine if controls are effectively reducing element (e.g., $\mathrm{Cr}^{\mathrm{VI}}$, nickel, and manganese) and ozone concentrations below occupational evaluation criteria. Worker exposures should also be re-evaluated after any process changes in the facilities to determine the level of exposures under new conditions.

4. Eating, drinking, or smoking should not be allowed in work areas. Workers should also change out of contaminated clothing and wash thoroughly to remove any contaminants prior to eating, drinking, smoking, or leaving work (to prevent any possible contamination of vehicles or homes).

5. The plant's safety/ergonomics team which consists of management and worker representatives should continue scheduled meetings to address health and safety issues within the workplace. Employees with work-related health concerns should be encouraged to report these concerns to the safety/ergonomics team representatives.

6. Housekeeping practices should be improved to reduce secondary exposures to contaminants. Dry-sweeping in the facilities should be prohibited. Wet clean-up methods (i.e., mopping) or vacuuming with an approved HEPA filter vacuum should be utilized during clean-up activities. Wet clean-up methods should not be used in any area where they may cause a potential electrical or safety hazard.

7. OSHA regulations that pertain to fall protection in this industry must be followed to protect workers from potential fall hazards.

\section{REFERENCES}

1. NIOSH [1994]. Cassinelli, M.E. \& O'Connor, P.F., Eds. NIOSH manual of analytical methods. 4th ed. U.S. Department of Health and Human Services, Public Health Service, Centers for Disease Control, National Institute for Occupational Safety and Health, DHHS (NIOSH) Publication No. 94-113.

2. NIOSH [1992]. Recommendations for occupational safety and health: compendium of policy documents and statements. Cincinnati, $\mathrm{OH}$ : U.S. Department of Health and Human Services, Public Health Service, Centers for Disease Control and Prevention, National Institute for Occupational Safety and Health, DHHS (NIOSH) Publication No. 92-100.

3. ACGIH [2003]. 2003 TLVs ${ }^{\circledR}$ and BEIs ${ }^{\circledR}$ : threshold limit values for chemical substances and physical agents. Cincinnati, $\mathrm{OH}$ : American Conference of Governmental Industrial Hygienists.

4. CFR [1997]. 29 CFR 1910.1000. Code of Federal Regulations. Washington, DC: U.S. Government Printing Office, Office of the Federal Register.

5. Hathaway $\mathrm{G}$ et al, eds. [1991]. Proctor and Hughes' chemical hazards of the workplace, 3rd 
ed. New York, NY: Van Nostrand Reinhold.

6. NIOSH [1997]. NIOSH Pocket Guide to Chemical Hazards, Cincinnati, OH: U.S. Department of Health and Human Services, Public Health Service, Centers for Disease Control and Prevention, National Institute for Occupational Safety and Health, DHHS (NIOSH) Publication No. 97-140.

7. IARC [1985]. IARC Monographs on the evaluation of the carcinogenic risk of chemicals to humans. Tobacco Smoking. Volume 38. Lyon: World Health Organization. [International Agency for research on Cancer.]

8. ACGIH [1991]. Nickel and Inorganic Compounds. In: Documentation of the threshold limit values and biological exposure indices, Sixth ed. Cincinnati, OH: American Conference of Governmental Industrial Hygienists, Inc, BEI-69.

9. NIOSH [1981]. Occupational health guidelines for chemical hazards. Cincinnati, $\mathrm{OH}$ : U.S. Department of Health and Human Services, Public Health Service, Centers for Disease Control, National Institute for Occupational Safety and Health, DHHS (NIOSH)/DOL (OSHA) Publication No. 81-123 and supplements 88-118, 89-104.

10. Karen E. Stine and Thomas M. Brown. [1996]. Principles of Toxicology, Lewis Publishers, CRC Press, Inc. Boca Raton, Florida. page 206.

11. WHO [1981]. Environmental Health Criteria 17: Manganese. Geneva, Switzerland. World Health Organization.

12. Tanaka S [1993]. Manganese and its compounds. In: Zenz C, Dickerson OB, Horvath E (eds.). Occupational medicine: Principles and practical applications, 3rd ed. Chicago: Year Book Medical Publishers, Inc.

13. Mena I, Horiuchi K, Burke K, Cotzias GC [1969]. Chronic manganese poisoning: individual susceptibility and absorption of iron. Neurology 19:1000-1006.
14. NIOSH [1988]. NIOSH testimony on OSHA's proposed rule on air contaminants. Compendium of policy documents and statements. Cincinnati, OH: U.S. Department of Health and Human Services, Public Health Service, Centers for Disease Control, National Institute for Occupational Safety and Health, NTIS No. PB-90-115-337.

15. ACGIH [2001]: Industrial Ventilation, A Manual of Recommended Practice, $24^{\text {th }}$ edition. Cincinnati, OH: American Conference of Governmental Industrial Hygienists.

16. CFR [1996]. 29 CFR 1910.134. Code of Federal regulations. Washington, DC: U.S. Government Printing Office, Office of the Federal Register.

17. NIOSH [1997]. NIOSH Respirator Use Policy for Protection Against Carcinogens. U.S. Department of Health and Human Services, Public Health Service, Centers for Disease Control and Prevention, National Institute for Occupational Safety and Health, RUP 1.0.

18. Campbell DL, Coffey CC, Lenhart SW [2001]. Respiratory Protection as a Function of Respirator Fitting Characteristics and Fit-Test Accuracy. Am Ind Hyg Assoc J 62:36-44.

19. CFR [1996]. 29 CFR 1910.23. Walking-Working Surfaces. Code of Federal regulations. Washington, DC: U.S. Government Printing Office, Office of the Federal Register.

20. Sjogren B, Hansen KS, Kjuus H, Persson P [1994]. Exposure to stainless steel welding fumes and lung cancer; a meta-analysis. Occup Environ Med 51:335-336.

21. Grimsrud TK, Berge SR, Haldorsen T, Andersen A [2002]. Exposure to Different Forms of Nickel and Risk of Lung Cancer. Am J Epidemiol 156:1123-1132. 
Trame 
Table 1

Personal Breathing Zone (PBZ) sample results for nickel, chromium, and manganese

HETA 2003-0144-2924

Felker Brothers Corporation

\begin{tabular}{|c|c|c|c|c|c|}
\hline $\begin{array}{l}\text { Sample } \\
\text { Number }\end{array}$ & Task/Location & Nickel $\left(\mathbf{m g} / \mathbf{m}^{3}\right)$ & $\begin{array}{c}\text { Chromium } \\
\left(\mathrm{mg} / \mathrm{m}^{3}\right)\end{array}$ & $\begin{array}{c}\text { Manganese } \\
\left(\mathrm{mg} / \mathrm{m}^{3}\right)\end{array}$ & $\begin{array}{c}\text { Sample } \\
\text { Time } \\
\text { (minutes) }\end{array}$ \\
\hline $\begin{array}{l}343 \& \\
355\end{array}$ & Burner operations & TWA $=\mathbf{0 . 0 3 2}$ & TWA $=\mathbf{0 . 0 7 2}$ & TWA $=0.042$ & $\begin{array}{l}\text { Total Time } \\
(n=2) 277\end{array}$ \\
\hline 327 & Depot Facility & 0.0197 & 0.034 & 0.01 & 415 \\
\hline $\begin{array}{l}382 \& \\
378\end{array}$ & $\begin{array}{l}\text { Department } 206 \\
\text { Welding/Grinding } \\
\text { inside pipe }\end{array}$ & $\mathrm{TWA}=\mathbf{0 . 1 2 2}$ & $\mathrm{TWA}=0.26$ & $\mathrm{TWA}=\mathbf{0 . 3 4}$ & $\begin{array}{l}\text { Total Time } \\
(n=2) 443\end{array}$ \\
\hline $\begin{array}{l}400 \& \\
375\end{array}$ & $\begin{array}{l}\text { Department } 206 \\
\text { Welding/Grinding } \\
\text { inside pipe }\end{array}$ & $\mathbf{T W A}=\mathbf{0 . 1 5}$ & $\mathrm{TWA}=\mathbf{0 . 3 6}$ & TWA $=0.32$ & $\begin{array}{l}\text { Total Time } \\
(n=2) 439\end{array}$ \\
\hline $\begin{array}{l}389 \& \\
394\end{array}$ & $\begin{array}{l}\text { Department } 206 \\
\text { Welding/Grinding } \\
\text { Fins on pipe }\end{array}$ & $\mathrm{TWA}=0.16$ & $\mathbf{T W A}=\mathbf{0 . 3 6}$ & $\mathbf{T W A}=\mathbf{0 . 3 1}$ & $\begin{array}{l}\text { Total Time } \\
(n=2) 423\end{array}$ \\
\hline 383 & $\begin{array}{l}\text { Machine } \\
\text { operator (angle } \\
\text { rings) }\end{array}$ & 0.015 & 0.03 & 0.009 & 432 \\
\hline 371 & $\begin{array}{l}\text { Utility Worker } \\
\text { Department } 108\end{array}$ & 0.017 & 0.032 & 0.007 & 407 \\
\hline 381 & $\begin{array}{l}\text { Department } 206 \\
\text { cutting/welding/ } \\
\text { grinding }\end{array}$ & 0.018 & 0.04 & 0.029 & 278 \\
\hline $\begin{array}{l}344 \& \\
334\end{array}$ & $\begin{array}{l}\text { Department } 206 \\
\text { cutting/welding/ } \\
\text { grinding }\end{array}$ & 0.021 & 0.043 & 0.015 & $\begin{array}{l}\text { Total Time } \\
(n=2) 448\end{array}$ \\
\hline $\begin{array}{l}345 \& \\
372\end{array}$ & Fabricator & 0.052 & 0.087 & 0.042 & $\begin{array}{l}\text { Total Time } \\
(n=2) 415\end{array}$ \\
\hline $\begin{array}{l}342 \& \\
332 \\
\end{array}$ & Fabricator & 0.156 & 0.24 & 0.08 & $\begin{array}{l}\text { Total Time } \\
(\mathrm{n}=2) 416\end{array}$ \\
\hline 360 & Grinding/Oven & 0.045 & 0.066 & 0.013 & 287 \\
\hline
\end{tabular}


Table 2

Personal Breathing Zone (PBZ) sample results for Hexavalent Chromium $\left(\mathrm{Cr}^{\mathrm{VI}}\right)$ exceeding NIOSH REL

HETA 2003-0144 -2924

Felker Brothers Corporation

\begin{tabular}{|c|c|c|c|}
\hline $\begin{array}{l}\text { Sample } \\
\text { Number }\end{array}$ & Worker Task/Location & $\begin{array}{c}\mathrm{Cr}^{\mathrm{VI}} \text { Concentration } \\
\left(\mathrm{mg} / \mathrm{m}^{3}\right)\end{array}$ & $\begin{array}{l}\text { Sample Time } \\
\text { (minutes) }\end{array}$ \\
\hline $\begin{array}{l}\text { HC26 \& } \\
\text { HC28 }\end{array}$ & $\begin{array}{l}\text { Department } 206 \\
\text { Welding/Grinding inside pipe }\end{array}$ & TWA $=0.005$ & $\begin{array}{l}\text { Total Time }=443 \\
(n=2)\end{array}$ \\
\hline $\begin{array}{l}\text { HC27 \& } \\
\text { HC29 }\end{array}$ & $\begin{array}{l}\text { Department } 206 \\
\text { Welding/Grinding inside pipe }\end{array}$ & $\mathbf{T W A}=\mathbf{0 . 0 2}$ & $\begin{array}{l}\text { Total Time }=439 \\
(n=2)\end{array}$ \\
\hline $\begin{array}{l}\text { HC38 \& } \\
\text { HC33 }\end{array}$ & $\begin{array}{l}\text { Department } 206 \\
\text { Welding/Grinding Fins on } \\
\text { pipe }\end{array}$ & TWA $=0.02$ & $\begin{array}{l}\text { Total Time }=423 \\
(n=2)\end{array}$ \\
\hline $\begin{array}{l}\text { HC70 \& } \\
\text { HC68 }\end{array}$ & Fabrication Fitter & TWA $=0.008$ & $\begin{array}{l}\text { Total Time }=416 \\
(n=2)\end{array}$ \\
\hline $\begin{array}{l}\text { HC73 \& } \\
\text { HC64 }\end{array}$ & Assembly/Tack Welder & TWA $=0.001$ & $\begin{array}{l}\text { Total Time }=424 \\
(n=2)\end{array}$ \\
\hline $\begin{array}{l}\text { HC23 \& } \\
\text { HC66 }\end{array}$ & Fabrication Fitter & TWA $=0.004$ & $\begin{array}{l}\text { Total Time }=415 \\
(n=2)\end{array}$ \\
\hline $\begin{array}{l}\text { HC35 \& } \\
\text { HC67 }\end{array}$ & Burner & $\mathbf{T W A}=\mathbf{0 . 0 0 3}$ & $\begin{array}{l}\text { Total Time }=277 \\
(n=2)\end{array}$ \\
\hline HC13 & Fabrication Fitter & 0.0016 & 408 \\
\hline HC36 & $\begin{array}{l}\text { Department } 203 \\
\text { Header Line Welding }\end{array}$ & 0.002 & 421 \\
\hline $\mathrm{HC22}$ & Grinding/Oven & 0.001 & 287 \\
\hline
\end{tabular}


DEPARTMENT OF HEALTH AND HUMAN SERVICES Centers for Disease Control and Prevention

National Institute for Occupational Safety and Health

4676 Columbia Parkway

Cincinnati, OH 45226-1998

\section{OFFICIAL BUSINESS}

Penalty for private use $\$ 300$

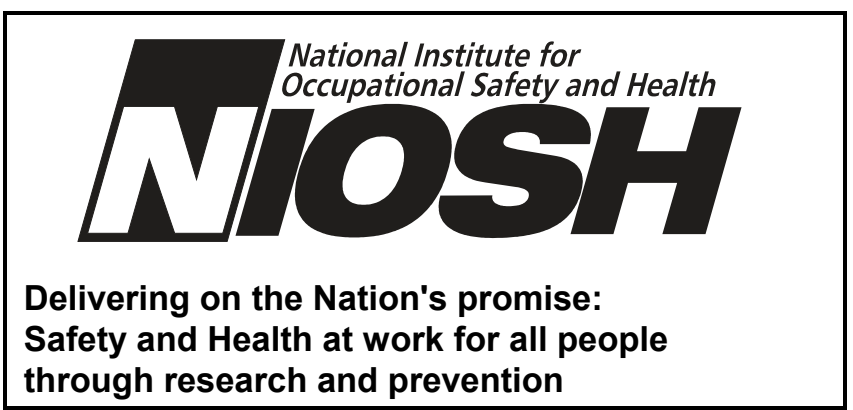

To receive $\mathrm{NIOSH}$ documents or information about occupational Safety and Health topics

contact NIOSH at:

1-800-35-NIOSH (356-4674)

Fax:1-513-533-8573

E-mail: pubstaft@cdc.gov

or visit the $\mathrm{NIOSH}$ web site at:

www.cdc.gov/niosh/homepage.html

SAFER • HEALTHIER - PEOPLE TM 

